\title{
PERANCANGAN APLIKASI PENDETEKSI TINGKAT KESAMAAN ANTAR DOKUMEN DENGAN ALGORITMA WINNOWING
}

\author{
Arnold Pramudita Tjiawi, Dyah E. Herwindiati, Lely Hiryanto \\ Teknik Informatika Universitas Tarumanagara \\ Jl. Letjen S.Parman No.1, Jakarta 11440 Indonesia \\ email :tjiawi.rush@gmail.com
}

\begin{abstract}
Abstrak
Perancangan aplikasi pendeteksian tingkat kesamaan antar dokumen ini dimaksudkan untuk menyimpan data tesis mahasiswa dan aplikasi dapat digunakan untuk membandingkan data skripsi mahasiswa dengan data baru yang ada. Hasil dari proses deteksi adalah persentase tingkat kesamaan. Algoritma yang digunakan dalam merancang aplikasi ini adalah Algoritma Winnowing. Algoritma ini termasuk dalam salah satu metode fingerprinting dokumen. Algoritma ini menggunakan rolling hashing untuk melakukan proses hashing dan menggunakan koefisien jaccard untuk menghitung tingkat kemiripan. Dalam pengujian aplikasi ini dengan data dummy diketahui bahwa aplikasi ini sangat bergantung pada urutan masing-masing lokasi substring. Aplikasi ini juga telah diuji untuk membandingkan sejumlah data skripsi yang ada dengan persentase tingkat kesamaan di bawah 30\%. Aplikasi ini tidak bisa menentukan apakah sebuah dokumen plagiat atau tidak, namun aplikasi ini bisa memberikan informasi berupa persentase tingkat kesamaan dan persentase dapat digunakan oleh pihak yang memiliki wewenang untuk menentukan.
\end{abstract}

Kata kunci-Algoritma Winnowing, plagiarisme,rolling hashing, tingkat kesamaan antar dokumen, jaccard coefficient

\begin{abstract}
The design of detection application for similarity level between documentsis intended to store student thesis data and applications can be used to compare a student thesis data with existing with new data. The result of the detection process is the percentage of similarity level. The algorithm used in designing this application is winnowing algorithm. This algorithm is included in one of the document fingerprinting methods. This algorithm uses rolling hashing to do the hashing process and use jaccard coefficient to calculate the similarity level. In testing this application with dummy data it is found that this application is very dependent on the order of each substring location. This application has also been tested to compare a number of existing thesis data with a percentage of similarity rate below 30\%. This application can not specify a plagiarism document or not, but this application can provide information in the form of percentage level of similarity and percentage can be used by who has the authority to determine.
\end{abstract}

Keywords-Document Fingerprinting, Jaccard Coefficient, Plagiarism, Rolling Hasihing, Similarity, Winnowing algorithm 


\section{PENDAHULUAN}

Penulisan karya ilmiah dalam lingkup pendidikan tinggi merupakan suatu hal yang wajib ada. Pada jenjang Strata satu (S1) dikenal makalah dan skripsi (tugas akhir). Dalam penulisan skripsi biasa diperlukan data ataupun informasi-informasi pendukung. Penulisan karya ilmiah tidak terlepas dari sumber-sumber pustaka yang dijadikan acuan penulisan. Sumber-sumber pustaka didapat dari buku, koran, majalan jurnal dan media tulis lainnya. Data dan informasi ini dapat dengan mudah diakses dengan adanya kemajuan teknologi informasi yang ada sekarang. Tetapi kemudahan ini memiliki efek negatif, seperti penjiplakan terhadap karya ilmiah orang lain. Hal ini berbahaya dan merugikan bagi pemilik karya ilmiah maupun bagi institusi tempat penjiplak berada.

Kegiatan penjiplakan ini biasa disebut sebagai plagiarisme. Plagiarisme ini sulit untuk di deteksi jika dengan kasat mata, karena banyaknya informasi-informasi yang biasa terdapat dalam sebuah karya ilmiah. Untuk itu diperlukan sebuah perancangan aplikasi pendeteksi tingkat kesamaan antar dokumen. Aplikasi yang dirancang ini akan menggunakan algoritma winnowing. Algoritma ini menggunakan rolling hashing untuk melakukan hashing dan menggunakan jaccard coefficient untuk menghitung tingkat kesamaan. Hasil yang diharapkan dari aplikasi ini adalah sebuah prosentase tingkat kesamaan antar dokumen satu dengan dokumen lainnya, sehingga prosentase ini dapat digunakan untuk mengambil keputusan oleh pemilik otoritas.

\section{DASAR TEORI}

\subsection{Plagiarisme}

Plagiarisme merupakan sebuah tindakan plagiat atau melakukan plagiat. Plagiat atau penjiplakan adalah pengambilan karangan, pendapat, dan sebagainya orang lain dan menjadikannya seolah karangan dan pedapat sendiri. Misalnya menerbitkan karya tulis orang lain yang belum sempat diterbitkan oleh penulisnya atas nama diri sendiri[1]. Metode untuk mendeteksi plagiarisme dapat dibagi menjadi tiga bagian, yaitu metode perbandingan teks lengkap, metode dokumen fingerprinting, dan metode kesamaan kata kunci[2]. Metode yang digunakan dalam perancangan ini adalah metode dokumen fingerprinting. Metode ini menggunakan teknik hashing, berikut adalah beberapa algoritmanya yaitu rabin-karp, winnowing, dan manber. Pada perancangan ini digunakan algoritma winnowing.

\subsection{Algoritma Winnowing}

Algoritma winnowing merupakan salah satu metode dalam dokumen fingerprinting. Input dari algoritma ini adalah dokumen teks yang diproses sehingga mendapatkan output nilai hash. Algoritma yang digunakan untuk mendapatkan nilai hash pada winnowing adalah rolling hashing. Berikut ini tahapan proses dalam algoritma winnowing :

1. Text Pre-processing

Dalam proses ini dokumen teks diolah agar menjadi data siap proses. Pengolahan ini meliputi spasi, jenis huruf (kapital atau normal), tanda baca dan sebagainya (whitespace insensitivity).

Contoh teks:

Indonesia tanah air Beta.

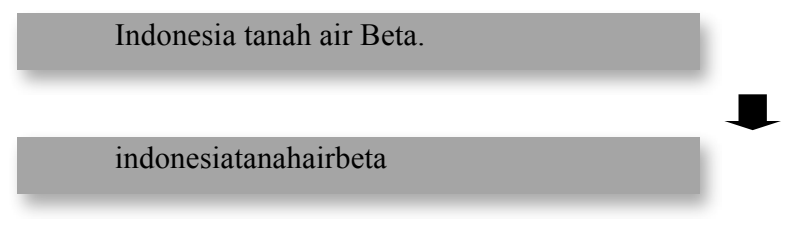


2. Membentuk rangkaian k-grams dari teks

Percobaan menggunakan nilai $\mathrm{k}$-grams $=5$, berikut ini contohnya :

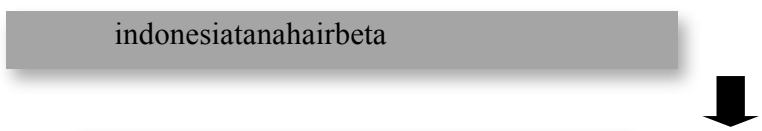

indon ndone dones onesi nesia esiat siata iatan atana tanah anaha nahai ahair hairb airbe irbet rbeta

3.Melakukan rolling hashing untuk setiap k-grams

Persamaan (1) adalah perhitungan fungsi hash dari algoritma winnowing dengan c sebagai nilai ASCII, $b$ sebagai nilai basis bilangan prima, dan banyak karakter $\mathrm{k}$ [3] :

$H_{(c 1 \ldots c k)}=c_{1} * b^{(k-1)}+c_{2} * b^{(k-2)}+\cdots+c_{n-1} * b+c_{k}$

Berikut ini contoh pernggunaan rolling hashing pada dokumen teks yang sudah melewati proses nomor 2. Dengan menggunakan nilai $b=11$.

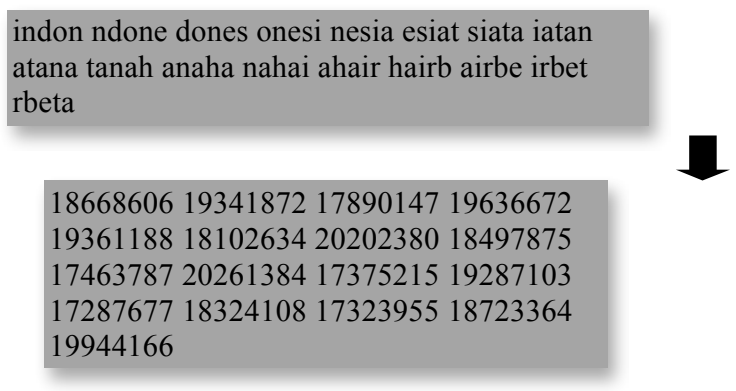

4. Memilih nilai fingerprint dari hasil hashing dengan pembagian hasil hash berdasarkan satu nilai window merupakan hasil dari perhitungan $w=\mathrm{t}-\mathrm{k}+1$ [3].

Misalkan nilai $\mathrm{t}=8$, sehingga $\mathrm{w}=8-5+1=4$. Dalam satu ukuran window dapat terisi dengan 4 nilai hash.

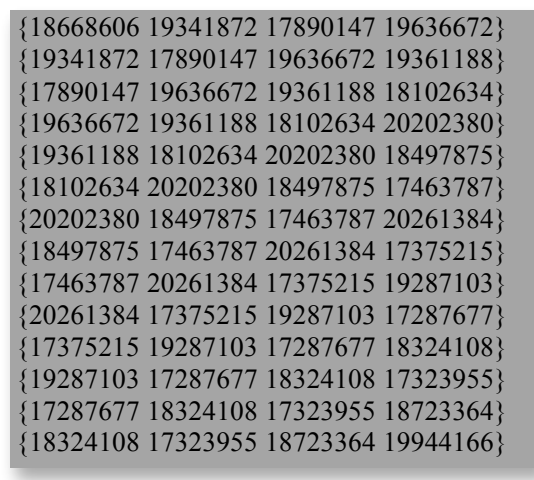

Setelah window terbentuk sebanyak 14 buah, maka dicarilah nilai fingerprint dengan melihat nilai terkecil dari setiap window. Maka didapati nilai fingerprint : 17890147 18102634174637871737521517287677 17323955. Dari 14 window hanya terdapat 6 fingerprint, hal ini disebabkankarena ada beberapa window yang memiliki nilai terendah yang sama sehingga tidak perlu dituliskan kembali.

5. Menghitung tingkat kemiripan

Untuk menghitung tingkat kemiripan diperlukan minimal dua buah dokumen teks untuk dibandingkan. Carany dengan mengikuti dari proses ke-1 hingga mendapatkan fingerprint dari setiap dokumen teks, lalu akan digunakan jaccard coefficient untuk menghitung kesamaannya. 
Similarity $\left(d_{i}, d_{j}\right)=\frac{\left|w\left(d_{i}\right) \cap w\left(d_{j}\right)\right|}{\left|w\left(d_{i}\right) \cup w\left(d_{j}\right)\right|} \times 100 \%$

Misalkan file teks $D_{1}$ dan $D_{2}$ dengan fingerprint $D_{1}=17890147,18102634,17463787$, 1737521517287677,17323955 dan fingerprint $D_{2}=17890147,18102524,17318708$ maka sesuai dengan persamaan (2) diperoleh nilai kesamaan sebesar 12.5\%

$$
\text { Similarity }\left(d_{i}, d_{j}\right)=\frac{|1|}{|8|} \times 100 \%=12.5 \%
$$

\subsection{Penentuan Nilai Parameter}

Penentuan nilai parameter untuk pengujian sudah dilakukan berdasarkan pengujian yang sudah pernah dilakukan oleh Milani Winangga, Drs. Marji, M.T., dan Drs. Achmad Ridok, M.Kom. Kinerja terbaik diperoleh pada konfigurasi parameter nilai $\mathrm{kgram}=5$, threshold $=25$, dan basis=11 dengan hasil tingkat prosentase error yang berbanding lurus dengan prosentase perubahan dokumen [4].

\subsection{Sistem yang Dibuat}

Sistem aplikasi pendeteksi tingkat kesamaan antar dokumen dengan algoritma winnowing ini memiliki alur yang dapat dilihat pada Gambar 1. Pada proses pendeteksian diperlukan untuk menentukan nilai k-grams, guarantee threshold (threshold), dan basis. Setelah itu user harus memasukkan dokumen uji dengan format ekstensi .docx serta memilih dokumen pembanding yang sudah ada datanya dalam aplikasi. Selanjutnya proses akan menjalankan proses dengan algoritma winnowing. Jika aplikasi sudah menjalankan urutan proses dalam algoritma winnowing maka akan didapati hasil prosentase tingkat kesamaan serta menampilkan kata yang sama. Prosentase ini dapat dilihat dan digunakan sebagai data untuk menentukan apakah dokumen uji tersebut plagiat atau tidak. Penentuan ini ditentukan oleh pihak yang memiliki otoritas dalam menentukan dan aplikasi hanya menampilkan prosentase tingkat kesamaan.

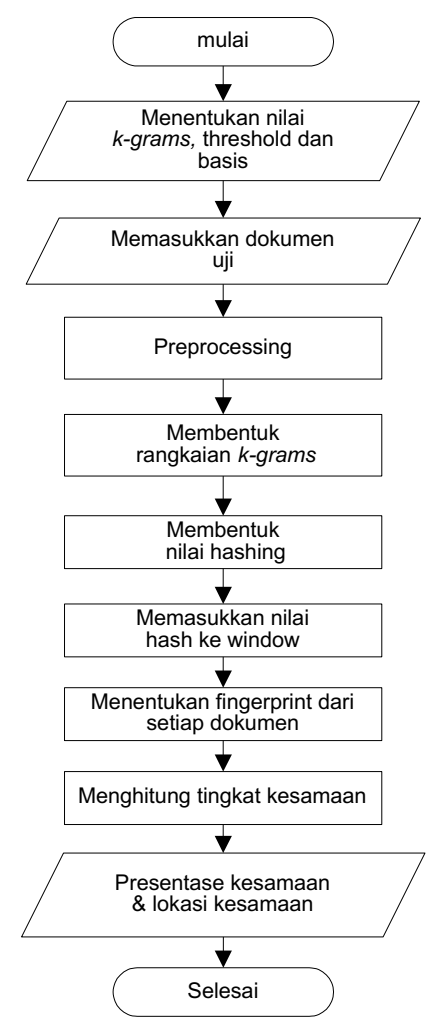

Gambar 1 Alur kerja sistem yang di buat 


\section{HASIL DAN PEMBAHASAN}

Pengujian dilakukan terhadap aplikasi pendeteksi tingkat kesamaan antar dokumen dengan algoritma winnowing ini. Pengujian dibagi menjadi 2 yaitu pengujian terhadap modul dan pengujian terhadap data. Pengujian terhadap modul ini dilakukan untuk memastikan bahwa setiap modul dapat berjalan dan berfungsi dengan baik. Sedangkan untuk pengujian tehadap data dilakukan untuk memastikan bahwa penerapan algoritma winnowing pada aplikasi ini sudah berjalan sesuai dengan yang diharapkan.

Hasil pengujian terhadap modul menghasilkan bahwa setiap modul dapat berjalan dengan baik. Berikut ini daftar modul yang ada dalam aplikasi :

- Modul Login

- Modul Home

- Modul Mahasiswa

- Modul Dosen

- Modul Archieve

- Modul Deteksi

- Modul Hasil

- Modul Unggah Skripsi

- Modul Log Out

Pengujian terhadap data dilakukan dengan 2 tahap, yaitu tahap pertama dengan data dummy dan tahap kedua dengan data skripsi asli. Pengujian dengan data dummy ini untuk memastikan bahwa algoritma dalam aplikasi berjalan sesuai yang diharapkan dan untuk mencoba kinerja aplikasi. Sedangkan untuk pengujian terhadap data skripsi asli untuk memastikan bahwa aplikasi dapat berjalan sesuai dengan yang diharapkan.

Untuk pengujian menggunakan data dummy telah dilakukan dengan sebuah dokumen teks yang berisi sebuah paragraf yang diatur komposisinya sebagai berikut :

- Data dummy $100 \%$ sama persis

- Data dummy dipotong $20 \%$ kata, sehingga tersisa $80 \%$ kata

- Data dummy dipotong $40 \%$ kata, sehingga tersisa $60 \%$ kata

- Data dummy dipotong $60 \%$ kata, sehingga tersisa $40 \%$ kata

- Data dummy dipotong $80 \%$ kata, sehingga tersisa $20 \%$ kata

- Data dummy diacak $20 \%$ kata, pengacakan dilakukan secara manual

- Data dummy diacak 60\% kata, pengacakan dilakukan secara manual

Hasil dari pengujian data dummy dapat dilihat pada Gambar 2.

\begin{tabular}{|c|c|c|c|c|c|c|}
\hline$\approx$ & FLLE 1 & FLE 2 (ARCAIEVE) & NILAI K & NLW B & NILAI W & PERSENTASE \\
\hline s. & dummy 100 sex & dummy 100.d00x & 5 & 11 & 21 & 100 \\
\hline 39. & dummy 80 (putong 20) doce & dummy $100.800 x$ & 5 & 11 & 21 & 76.92 \\
\hline 40. & dummy 60 (potong 40) docx & dammy $100 . d 0 c x$ & 5 & 11 & 21 & 61.54 \\
\hline 41. & dummy 40 (potong 60) docr & dummin 100:A0cx & 5 & 11 & 21 & 38.46 \\
\hline 42 & dummy 20 (phong 80) docx & dummy $100.400 x$ & 5 & 11 & 21 & 1538 \\
\hline 43. & dummy acak $20 . d 0 c x$ & demmy $100.400 x$ & 5 & 11 & 21 & 53.13 \\
\hline 4. & dummy acak 60 .docx & demmy $100.80 c x$ & 5 & 11 & 21 & 23.68 \\
\hline
\end{tabular}

Gambar 2 Hasil pengujian data dummy

Pengujian terhadap data skripsi asli menggunakan laporan skripsi dari 18 orang mahasiswa. Laporan tersebut dipecah menjadi 3 bagian yaitu BAB I, BAB III, dan BAB IV. Pengujian dilakukan dengan mengambil data $\mathrm{BAB}$ I seorang mahasiswa dan dibandingkan 
dengan 18 data lainnya. Berikut ini hasil pengujian BAB I bisa dilihat di Gambar 3, pengujian pada BAB III dapat dilihat di Gambar 4, dan pengujian pada BAB IV dapat dilihat di Gambar 5

\begin{tabular}{|c|c|c|c|c|c|c|}
\hline$\# \star$ & FILE 1 & Ff FLLE 2 (ARCHIEVE) & NILAI K & NILAI B & NILAI W & PERSENTASE \\
\hline 8. & BAB 1 (Paryanka Victorius Abadi).docx & BAB 1 (Ayu Windy Astuti).docx & 5 & 11 & 21 & 22.56 \\
\hline 9. & BAB 1 (Paryanka Victorius Abadi).docx & BAB 1 (Elizabeth Erlsha).docx & 5 & 11 & 21 & 14.81 \\
\hline 10. & BAB 1 (Paryanka Victorius Abadi).docx & BAB 1 (Farenco).docx & 5 & 11 & 21 & 19.62 \\
\hline 11. & BAB 1 (Paryanka Victorius Abadi).docx & BAB 1 (Ferry Dharmawan).docx & 5 & 11 & 21 & 13.41 \\
\hline 12. & BAB 1 (Paryanka Victorius Abadi).docx & BAB 1 (Fransisca Regina).docx & 5 & 11 & 21 & 17.1 \\
\hline 13. & BAB 1 (Paryanka Victorius Abadi).docx & BAB 1 (Irawati Djajadi).docx & 5 & 11 & 21 & 19.86 \\
\hline 14. & BAB 1 (Paryanka Victorius Abadi).docx & BAB 1 (Jacklin Shintia Thio).docx & 5 & 11 & 21 & 21.32 \\
\hline 15. & BAB 1 (Paryanka Victorius Abadi).docx & BAB 1 (Josselyn Shintia Thio).docx & 5 & 11 & 21 & 20.84 \\
\hline 16. & BAB 1 (Paryanka Victorius Abadi).docx & BAB 1 (Mariana).docx & 5 & 11 & 21 & 21.8 \\
\hline 17. & BAB 1 (Paryanka Victorius Abadi).docx & BAB 1 (Mishelle Tirta Winarta).docx & 5 & 11 & 21 & 18.53 \\
\hline 18. & BAB 1 (Paryanka Victorius Abadi).docx & BAB 1 (Nadia Yanitra).docx & 5 & 11 & 21 & 18.07 \\
\hline 19. & BAB 1 (Paryanka Victorius Abadi).docx & BAB 1 (Renaldo Ali).docx & 5 & 11 & 21 & 15.66 \\
\hline 20. & BAB 1 (Paryanka Victorius Abadi).docx & BAB 1 (Rionaldy Triasaputra).docx & 5 & 11 & 21 & 13.44 \\
\hline 21. & BAB 1 (Paryanka Victorius Abadi).docx & BAB 1 (Rosalinda).docx & 5 & 11 & 21 & 17.28 \\
\hline 22. & BAB 1 (Paryanka Victorius Abadi).docx & BAB 1 (Paryanka Victorius Abadi).docx & 5 & 11 & 21 & 100 \\
\hline 23. & BAB 1 (Paryanka Victorius Abadi).docx & BAB 1 (Sri Whisnu A.W).docx & 5 & 11 & 21 & 26.64 \\
\hline 24. & BAB 1 (Paryanka Victorius Abadi).docx & BAB 1 (Vina Tendean).docx & 5 & 11 & 21 & 18.12 \\
\hline 25. & BAB 1 (Paryanka Victorius Abadi).docx & BAB 1 (Yunita).docx & 5 & 11 & 21 & 19.07 \\
\hline
\end{tabular}

Gambar 3 Pengujian pada BAB I

\begin{tabular}{|c|c|c|c|c|c|c|}
\hline$\#$ & FILE 1 & FILE 2 (ARCHIEVE) & NILAIK & NILAI B & NLLAIW & PERSENTASE \\
\hline 26. & BAB 3 (Paryanka Victorius Abadi).docx & BAB 3 (Ayu Windy Astuti).docx & 5 & 11 & 21 & 26.3 \\
\hline 27. & BAB 3 (Paryanka Victorius Abadi).docx & BAB 3 (Elizabeth Erlsha).docx & 5 & 11 & 21 & 18.08 \\
\hline 28. & BAB 3 (Paryanka Victorius Abadi).docx & BAB 3 (Farenco).docx & 5 & 11 & 21 & 19.6 \\
\hline 29. & BAB 3 (Paryanka Victorius Abadi).docx & BAB 3 (Ferry Dharmawan).docx & 5 & 11 & 21 & 20.15 \\
\hline 30. & BAB 3 (Paryanka Victorius Abadi).docx & BAB 3 (Fransisca Regina).docx & 5 & 11 & 21 & 20.55 \\
\hline 31. & BAB 3 (Paryanka Victorius Abadi).docx & BAB 3 (Irawati Djjajadi).docx & 5 & 11 & 21 & 18.54 \\
\hline 32. & BAB 3 (Paryanka Victorius Abadi).docx & BAB 3 (Mariana).docx & 5 & 11 & 21 & 21.04 \\
\hline 33. & BAB 3 (Paryanka Victorius Abadi).docx & BAB 3 (Mishelle Tirta Winarta).docx & 5 & 11 & 21 & 19.48 \\
\hline 34. & BAB 3 (Paryanka Victorius Abadi).docx & BAB 3 (Nadia Yanitra). docx & 5 & 11 & 21 & 18.66 \\
\hline 35. & BAB 3 (Paryanka Victorius Abadi).docx & BAB 3 (Renaldo Ali).docx & 5 & 11 & 21 & 15.63 \\
\hline 36. & BAB 3 (Paryanka Victorius Abadi).docX & BAB 3 (Rionaldy Triasaputra). docx & 5 & 11 & 21 & 15.74 \\
\hline 37. & BAB 3 (Paryanka Victorius Abadi).docx & BAB 3 (Rosalinda).docx & 5 & 11 & 21 & 18 \\
\hline 38. & BAB 3 (Paryanka Victorius Abadi).docx & BAB 3 (Paryanka Victorius Abadi).docx & 5 & 11 & 21 & 100 \\
\hline 39. & BAB 3 (Paryanka Victorius Abadi).docx & BAB 3 (Jacklin Shintia Thio).docx & 5 & 11 & 21 & 21.91 \\
\hline 40. & BAB 3 (Paryanka Victorius Abadi).docx & BAB 3 (Josselyn Shintia Thio).docx & 5 & 11 & 21 & 20.52 \\
\hline 41. & BAB 3 (Paryanka Victorius Abadi).docx & BAB 3 (Sri Whisnu A.W. docx & 5 & 11 & 21 & 29.11 \\
\hline 42. & BAB 3 (Paryanka Victorius Abadi).docx & BAB 3 (Vina Tendean).docx & 5 & 11 & 21 & 20.84 \\
\hline 43. & BAB 3 (Paryanka Victorius Abadi).docx & BAB 3 (Yunita).docx & 5 & 11 & 21 & 20.09 \\
\hline
\end{tabular}

Gambar 4 Pengujian pada BAB III

\begin{tabular}{|c|c|c|c|c|c|c|}
\hline$\#{ }^{*}$ & FILE 1 & FLLE 2 (ARCHIEVE) & NILAIK & NILAI B & NILAI W & PERSENTASE \\
\hline 44. & BAB 4 (Paryanka Victorius Abadi).docx & BAB 4 (Ayu Windy Astuti).docx & 5 & 11 & 21 & 19.52 \\
\hline 45. & BAB 4 (Paryanka Victorius Abadi).docx & BAB 4 (Elizabeth Erlsha).docx & 5 & 11 & 21 & 10.83 \\
\hline 46. & BAB 4 (Paryanka Victorius Abadi).docx & BAB 4 (Farenco).docx & 5 & 11 & 21 & 19.9 \\
\hline 47. & BAB 4 (Paryanka Victorius Abadi).docx & BAB 4 (Ferry Dharmawan).docx & 5 & 11 & 21 & 12.97 \\
\hline 48. & BAB 4 (Paryanka Victorius Abad).docx & BAB 4 (Fransisca Regina).docx & 5 & 11 & 21 & 16.13 \\
\hline 49. & BAB 4 (Paryanka Victorius Abadi).docx & BAB 4 (Irawati Djajadi).docx & 5 & 11 & 21 & 14.97 \\
\hline 50. & BAB 4 (Paryanka Victorius Abadi).docx & BAB 4 (Jacklin Shintia Thio).docx & 5 & 11 & 21 & 22.23 \\
\hline 51. & BAB 4 (Paryanka Victorius Abadi).docx & BAB 4 (Josselyn Shintia Thio).docx & 5 & 11 & 21 & 19.42 \\
\hline 52. & BAB 4 (Paryanka Victorius Abadi).docx & BAB 4 (Mariana).docx & 5 & 11 & 21 & 23.08 \\
\hline 53. & BAB 4 (Paryanka Victorius Abadi).docx & BAB 4 (Mishelle Tirta Winarta).docx & 5 & 11 & 21 & 14.91 \\
\hline 54. & BAB 4 (Paryanka Victorius Abadi).docx & BAB 4 (Nadia Yanitra).docx & 5 & 11 & 21 & 12.89 \\
\hline 55. & BAB 4 (Paryanka Victorius Abad).docx & BAB 4 (Renaldo Ail).docx & 5 & 11 & 21 & 13.29 \\
\hline 56. & BAB 4 (Paryanka Victorius Abadi).docx & BAB 4 (Rionaldy Triasaputra).docx & 5 & 11 & 21 & 10.06 \\
\hline 57. & BAB 4 (Paryanka Victorius Abadi).docx & BAB 4 (Rosalinda).docx & 5 & 11 & 21 & 13.25 \\
\hline 58. & BAB 4 (Paryanka Victorius Abadi).docx & BAB 4 (Paryanka Victorius Abadi).docx & 5 & 11 & 21 & 100 \\
\hline 59. & BAB 4 (Paryanka Victorius Abadi).docx & BAB 4 (Sri Whisnu A.W. docx & 5 & 11 & 21 & 25.35 \\
\hline 60. & BAB 4 (Paryanka Victorius Abadi).docx & BAB 4 (Vina Tendean).docx & 5 & 11 & 21 & 15.73 \\
\hline 61. & BAB 4 (Paryanka Victorius Abadi).docx & BAB 4 (Yunita).docx & 5 & 11 & 21 & 15.15 \\
\hline
\end{tabular}


Gambar 5 Pengujian pada BAB IV

Pengujian selanjutnya adalah dengan membandingkan beberapa skripsi mahasiswa yang memiliki topik yang mirip, berikut ini daftarnya :

a. Pengujian antara Skripsi Farenco dengan Paryanka Victorius Abadi dapat dilihat pada Gambar 6.

\begin{tabular}{|l|l|l|l|l|l|}
\hline FILE 1 & FILE 2 (ARCHIEVE) & NILAI K & NILAI B & NILAI W & PERSENTAS \\
\hline BAB 1 (Paryanka Victorius Abadi).docx & BAB 1 (Farenco).docx & 5 & 11 & 21 & 19.62 \\
\hline BAB 3 (Paryanka Victorius Abadi).docx & BAB 3 (Farenco).docx & 5 & 11 & 21 & 19.6 \\
\hline BAB 4 (Paryanka Victorius Abadi).docx & BAB 4 (Farenco).docx & 5 & 11 & 21 & 19.9 \\
\hline
\end{tabular}

Gambar 12 Pengujian Skripsi Farenco dengan Paryanka

b. Pengujian antara Skripsi Fransisca Regina dengan Vina Tendean dapat dilihat pada Gambar 7.

\begin{tabular}{l|l|l|l|l|l}
\hline FILE 1 & FILE 2 (ARCHIEVE) & NILAI K & NILAI B & NILAI W & PERSENTASE \\
\hline BAB 1 (Vina Tendean).docx & BAB 1 (Fransisca Regina).docx & 5 & 11 & 21 & 27.97 \\
\hline BAB 3 (Vina Tendean).docx & BAB 3 (Fransisca Regina).docx & 5 & 11 & 21 & 36.81 \\
\hline BAB 4 (Vina Tendean).docx & BAB 4 (Fransisca Regina).docx & 5 & 11 & 21 & 22.37
\end{tabular}

Gambar 7 Pengujian Skripsi Fransisca Regina dengan Vina Tendean

c. Pengujian antara Skripsi Ferry Dharmawan dengan Renaldo Ali dapat dilihat pada Gambar 8.

\begin{tabular}{|c|c|c|c|c|c|}
\hline FILE 1 & FILE 2 (ARCHIEVE) & NILAI K & NILAI B & NILAI W & PERSENTASE \\
\hline BAB 1 (Ferry Dharmawan).docx & BAB 1 (Renaldo Ali).docx & 5 & 11 & 21 & 30.36 \\
\hline BAB 3 (Ferry Dharmawan).docx & BAB 3 (Renaldo Ali).docx & 5 & 11 & 21 & 20.6 \\
\hline BAB 4 (Ferry Dharmawan).docx & BAB 4 (Renaldo Ali).docx & 5 & 11 & 21 & 27.41 \\
\hline
\end{tabular}

Gambar 8 Pengujian Skripsi Ferry Dharmawan dengan Renaldo Ali

d. Pengujian antara Skripsi Ayu Windy, Jacklin Shintia Thio, Josselyn Shintia Thio, Mishelle Tirta, Nadia Yanitra, Sri Whisnu, dan Mariana dapat dilihat pada Gambar 9.

\begin{tabular}{|c|c|c|c|c|c|}
\hline FILE 1 & FILE 2 (ARCHIEVE) & NILAI K & NILAI B & NILAI W & PERSENTAS \\
\hline BAB 1 (Ayu Windy Astuti). docx & BAB 1 (Mariana).docx & 5 & 11 & 21 & 26.66 \\
\hline BAB 1 (Ayu Windy Astuti).docx & BAB 1 (Jacklin Shintia Thio).docx & 5 & 11 & 21 & 25.49 \\
\hline BAB 1 (Ayu Windy Astuti). docx & BAB 1 (Josselyn Shintia Thio).docx & 5 & 11 & 21 & 25.98 \\
\hline BAB 1 (Ayu Windy Astuti).docx & BAB 1 (Mishelle Tirta Winarta).docx & 5 & 11 & 21 & 20.57 \\
\hline BAB 1 (Ayu Windy Astuti).docx & BAB 1 (Nadia Yanitra).docx & 5 & 11 & 21 & 20.56 \\
\hline BAB 1 (Ayu Windy Astuti).docx & BAB 1 (Sri Whisnu A.W). docx & 5 & 11 & 21 & 21.82 \\
\hline BAB 3 (Ayu Windy Astuti).docx & BAB 3 (Josselyn Shintia Thio).docx & 5 & 11 & 21 & 29.03 \\
\hline BAB 3 (Ayu Windy Astuti).docx & BAB 3 (Mariana).docx & 5 & 11 & 21 & 27.13 \\
\hline BAB 3 (Ayu Windy Astuti).docx & BAB 3 (Mishelle Tirta Winarta).docx & 5 & 11 & 21 & 27.21 \\
\hline BAB 3 (Ayu Windy Astuti).docx & BAB 3 (Nadia Yanitra).docx & 5 & 11 & 21 & 24.31 \\
\hline BAB 3 (Ayu Windy Astuti).docx & BAB 3 (Sri Whisnu A.W) docx & 5 & 11 & 21 & 42.57 \\
\hline BAB 3 (Ayu Windy Astuti).docx & BAB 3 (Jacklin Shintia Thio).docx & 5 & 11 & 21 & 26.35 \\
\hline BAB 4 (Ayu Windy Astuti).docx & BAB 4 (Jacklin Shintia Thio).docx & 5 & 11 & 21 & 22.64 \\
\hline BAB 4 (Ayu Windy Astuti).docx & BAB 4 (Josselyn Shintia Thio).docx & 5 & 11 & 21 & 28.17 \\
\hline BAB 4 (Ayu Windy Astuti).docx & BAB 4 (Mariana).docx & 5 & 11 & 21 & 22.13 \\
\hline BAB 4 (Ayu Windy Astuti).docx & BAB 4 (Mishelle Tirta Winarta).docx & 5 & 11 & 21 & 15.07 \\
\hline BAB 4 (Ayu Windy Astuti).docx & BAB 4 (Nadia Yanitra).docx & 5 & 11 & 21 & 15.4 \\
\hline BAB 4 (Ayu Windy Astuti).docx & BAB 4 (Sri Whisnu A.W). docx & 5 & 11 & 21 & 22.94 \\
\hline
\end{tabular}




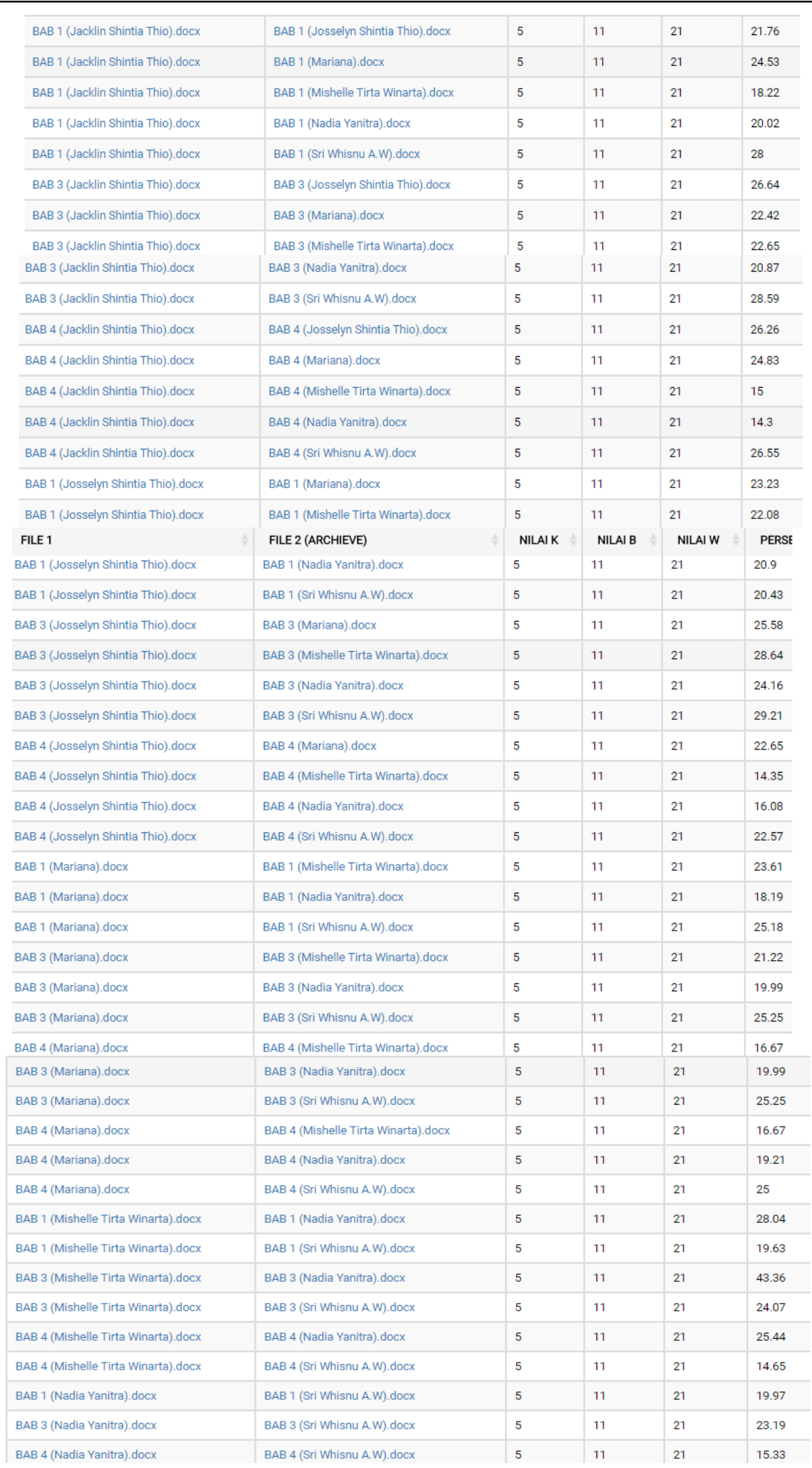

Gambar 9 Pengujian antara skripsi Ayu Windy, Jacklin Shintia Thio, Josselyn Shintia Thio, Mishelle Tirta, Nadia Yanitra, Sri Whisnu, dan Mariana 


\section{KESIMPULAN}

Kesimpulan yang dapat diperoleh berdasarkan pembuatan dan pengujian dari aplikasi pendeteksi tingkat kesamaan antar dokumen degan algoritma winnowing ini adalah sebagai berikut :

1. Aplikasi pendeteksi tingkat kesamaan antar dokumen ini dapat dijalankan dan mengoperasikan algoritma winnowing dengan baik serta dapat memberikan hasil yang dapat di tampilkan prosesnya.

2. Berdasarkan hasil pengujian diketahui bahwa susunan kata antar dokumen sangat menentukan nilai prosentase kesamaan. Jika urutan kata antar dokumen yang sama dirubah, maka hasilnya persentase kesamaannya akan turun.

3. Aplikasi dapat melakukan perbandingan dokumen uji dengan beberapa dokumen pembanding dan dapat ditampilkan secara bersamaan.

Saran untuk yang ingin mengembangkan aplikasi pendeteksi tingkat kesamaanantar dokumen dengan algoritma winnowing ini adalah sebagai berikut :

1. Dapat mengirimkan data hasil deteksi melalui email ketika proses deteksi sudah selesai

2. Menggunakan tambahan metode dokumen fingerprinting lainnya agar dapat digunakan sebagai tambahan informasi ukuran kesamaan antar dokumen.

\section{UCAPAN TERIMA KASIH}

Terima kasih saya ucapkan kepada dosen-dosen Fakultas Teknologi Informasi Universitas Tarumanagara yang sudah mau membimbing penulis dalam perancangan aplikasi ini. Terima kasih juga kepada seluruh pendahulu saya yang sudah digunakan data skripsinya untuk data pembanding dalam proses perancangan aplikasi ini.

\section{DAFTAR PUSTAKA}

[1] Depdikbud, 1997, Kamus Besar Bahasa Indonesia. Jakarta.

[2] Stein, Benno \& Eissen, Sven Meyer Zu. 2006. Fingerprint-based Similarity Search and its Applications. Bauhaus-Universitat Weimar.

[3] Schleimer, Saul. Wilkerson, Daniel S., dan Aiken, Alex. 2003. Winnowing : Local Algorithms for document Fingerprinting. San Diego.

[4] Milani W, Marji, Achmad Ridok. 2014. Deteksi Plagiarisme Pada Dokumen Teks Bahasa Indonesia Menggunakan Algoritma Winnowing Dengan Stemming. Malang : Universitas Brawijaya. 